\title{
Evaluation of the Impact of the Watu Ata Nature Reserve Policy Setting
}

\author{
Hendrikus Hironimus Botha ${ }^{1}$ \\ Didik G. Suharto ${ }^{2}$ \\ Rina Herlina Haryanti ${ }^{3}$
}

\begin{abstract}
The major theme of this paper is to evaluate policy impacts. This paper aims to evaluate the impact of the determination of the Watu Ata Nature Reserve using the evaluation criteria proposed by William N. Dunn: Effectiveness, Equity, Responsiveness and Appropriateness. As defined in RI Government Regulation No. 28 of 2011 Article 1, a nature reserve is an area which, due to its natural condition, contains unique plants and/or plant diversity along with natural phenomena and whose ecosystem requires protection and preservation efforts so that its existence and development can grow naturally. The Watu Ata Nature Reserve is one nature reserve area in the Ngada regency based on the Decree of Minister of Forestry No. 432/Kpts-II/92. The research method used is a descriptive qualitative study that employs a field study approach conducted in two villages, namely, Heawea Village and Inelika Village. These two villages have the biggest community's land in the Watu Ata Nature Reserve. The findings suggest that the Watu Ata Nature Reserve policy has had a negative impact on people living around the nature reserve area, particularly with respect to their loss of access to the cultivated land and cultural sites where they have built relationships with their deceased ancestors.
\end{abstract}

\section{Keywords:}

effectiveness; levelling; responsiveness; precision and loss of access.

\section{Introduction}

The standing position of this paper is to evaluate the impact of policy. One of the many policies the government has set focuses on environmental use and preservation. Setting aside forest areas as nature reserves is a step the government has taken to preserve forests.

Forests are natural resources that play an important role in the lives of all creatures. Thus, efforts to utilize and protect forests must be well-arranged to avoid the misuse of forests. Forest utilization and protection efforts have been established in Regulation No. 41 of 1999, which discusses forests and their functions. According to Regulation No. 41 of 1999, forest areas are divided into three groups: conservation forests, protected forests and production forests (Statistics of Forestry Ministry, 2013, p. 1). A conservation forest is a forest area with certain characteristics whose

\footnotetext{
${ }^{1}$ Public Administration Master Program, Faculty of Social and Political Sciences, University of Sebelas Maret Email: hendrabotha@gmail.com

2 Public Administration, Faculty of Social and Political Sciences, University of Sebelas Maret

3 Public Administration, Faculty of Social and Political Sciences, University of Sebelas Maret
} 
main function is to preserve the diversity of plants and animals as well as the ecosystem. A protected forest is a forest area whose main function is to protect the life support system by regulating the water system, preventing floods, controling erosion, preventing the intrusion of sea water, and maintaining soil fertility. A production forest is a forest area whose main function is to produce forest products. Production forests can be either Permanent Production Forests (HP), Limited Production Forests (HPT) or Converted Production Forests.

Anature reserve is one of the government's efforts to promote forest protection and conservation. Government Regulation of the Republic of Indonesia No. 28 of 2011 Article 1 defines a nature reserve area as a place whose natural condition includes unique plants and/or plant diversity, along with natural phenomena and whose ecosystem requires protection and conversation so that its existence and development can take place naturally. Nature reserves can be used only for certain activities, among them:

1. Research and development of science,

2. Education and awareness of nature conservation,

3. Carbon absorption and/or storage and

4. Utilization of germplasm source for cultivation support.

The government policy toward forest protection, through the establishment of forest areas as nature reserves, is a concrete step showing the government's attention toward and concern for forest preservation and sustainability. In essence, public policy should not settle a conflict with the values and social practices of a society (Subarsono, 2013, p. 3). However, many government policies have encountered resistance from society (pros and cons). This is because the policies did not accommodate the needs and interests of each group or individual, and had either positive or negative impacts. In essence, policies that are contrary to the values a society will encounter resistance when they are implemented (Subarsono, 2013, p. 3). This resistance comes from the society that the policies will harm. The success or failure of a policy will indicate its effectiveness in supporting the life of a nation and state; thus, Pareto (Mulyadi, 2015, p. 1) argues that public policy is a critical factor for a nation's progress and decline.

Public policy is a formulation process, implementation, and evaluation that are continuous and interlinked; it is conducted by the government with stakeholders that organize, manage and resolve various public affairs, public issues and public resources (Mulyadi, 2015, p. 3). However, often, a policy created to deal with an existing public issue creates other public issues. This happened in the area of the Watu Ata Nature Reserve. The policy of designating the Watu Ata forest area as a nature reserve negatively impacted the people who live there and whose lifestyles depend on the arable land that had been added to the Watu Ata Nature Reserve.

The Watu Ata Nature Reserve is one of the nature conservation areas in the Ngada Regency of NTT Province. Ten villages surround the nature reserve area: Wawowae, Beiwali, Susu, Naru, Langagedha, Bajawa, Kaligejo, Haewea, Inelika and Bomari. These ten villages have administrative areas which have become part of the Watu Ata Nature Reserve. The reserve's area is $4,898.80 \mathrm{Ha}$. The history of the setting of the Watu Ata Nature Reserve began in 1932, when the Dutch designated the Inelika Forest area as forest cover designated by CalenonhetZelfbestuurrabesluit Van Ngada do. June 29, 193220 (Koli, 2010, p. 26). This was accompanied by the enforcement of Agrarian Law (Wet), which is based on the principle of 'domeinverklaring'. This law stipulates that all land whose ownership cannot be proven becomes a state domain immediately. Most indigenous people did not have written proof of their land ownership, so they lost their land (National Inquiry Team of Komnas HAM, 2016, p. 30). 
Unfortunately, this setting is not a binding one. This is due to changes made by the government concerning either the area or its utilization. After Indonesia gained its independence, the area changed its status as a production forest in 1960 because the community was involved in forest management. In 1978/1980, people, along with the Ngada Regency government, undertook a reforestation project by planting Ampupu within the area.

In 1983, the forest group of Ngada Wolo Merah Riung (former Netherlands' forest cover) was established, by the decree of the Minister of Forestry No. 89/Kpts-II/1983 dated December 2,1983 , as forest cover with the function of a protected forest. The process of establishing the Watu Ata area as a nature reserve took place during the reign of Regent Drs. Joachim Reo (1989/1990). At that time, the border had changed, piercing into some gardens and community settlements. The ratification of the Watu Ata territory as a nature reserve was established by the decree of the Minister of Forestry No. 432/Kpts-II/92 (Koli, 2010, p. 26).

Unfortunately, the field facts showed that before the Watu Ata area became a nature reserve, some of its areas had been planted with coffee, cloves, candlenuts, rice, corn, and атрири. In addition, an approximately $7 \mathrm{~km}$ segment of BajawaAimerestreet that had been open since the Dutch era was also included in the nature reserve. This is contrary to the definition of the nature reserve itself, contained in Article 1, point 10 of Law No. 5 of 1990 on Conservation and Government Regulation No. RI. 28 the year 2011 Article 1 Paragraph 7, which states that land becomes a nature reserve area due to its natural state and peculiarity of plants, animals and ecosystems, or because its ecosystems require protection and that its development occurs naturally.

The people of these ten villages located around the area of the nature preserve face two difficult choices: complying with the government regulations (which means they must abandon agriculture as their source of income) or ignoring the government restrictions while maintaining fields and gardens that have been managed long before the establishment of the nature reserve area (which will subject them to consequences such as sanctions for violating the established regulations).

Therefore, fear exists among people, some of whom have surrendered and left their jobs. However, others chose to continue managing their fields and face sanctions. In the face of people's resistance, the government held a joint burning operation of 13 farmers' shacks at Lodo/Ghole on Thursday, November 14, 2002, conducted by joint officers of Ngada Police, the forest police of the Natural Resource Conservation Center (NRCC) II NTT and NRCC Resort Bajawa (Berdikari Online, May 10, 2011). This shack burning was not the first one that had occurred. The shack of a Wolokuru farmer was burned earlier, on August 2, 2001.

On one hand, people around the Watu Ata Nature Reserve must live under a problematic situation -1) facing the need to manage fields or gardens in the reserve area because their lives depend on those fields and 2) facing the obligation to comply with the existing regulations to protect the nature reserve area. On the other hand, the government has not considered contradictions in field facts in the area of the Watu Ata Nature Reserve with existing regulations. This indicates that the setting of the nature reserve area has a negative impact. One of these impacts is the marginalization of people in the area of the Watu Ata Nature Reserve. Limited space exists for people who live in the nature reserve area. The setting by the government has not been known yet by all people.

This paper aims to study the negative impacts experienced by people in the Watu Ata Nature Reserve. As stated before, a policy should accommodate all the social values that grow and develop in the community. In David Eston's view, when the government creates 
public policy, it allocates values to society because each policy contains a set of values within it (Subarsono, 2013, p. 3), and those values should align with society's values. This minimizes any inequality the policy may cause, such that people can benefit from a policy which is a representation of the government's alignment with and attention to existing public issues.

Thomas R. Dye, in Parsons (2008, p. 547), states that policy evaluation is "learning about the consequences of public policy". Furthermore, Anderson in Kusumanegara (2009, p. 121) discloses that policy evaluation focuses on the estimation, judgment and assessment of policies' implementation (processes) and effects (impacts). As a functional activity, a policy evaluation can be undertaken in all stages of a policy, not just in the final stage.

A policy can be stated or considered successful if it produces the expected impact. According to William Dunn, cited by Wibawa (1994, p. 5), "the impact of the policy is a change in physical and social conditions as a result of policy output." The output is goods, services or other facilities received by a particular group of people, either target groups or other groups that the policy intends to touch. Meanwhile,the output and impact themselves are consequences of the policy (Anton, 2014, p. 1012).

To evaluate the impact of the Watu Ata Nature Reserve setting policy, the author used the theory of William N. Dunn (2003, p. 429-438) related to the criteria of evaluation of a policy, namely: effectiveness, efficiency, adequacy, equity, responsiveness and appropriateness.

However, the author did not use all these criteria in their entirety; rather, the author selected four criteria deemed relevant for evaluating the policy of the Watu Ata Nature Reserve. The first is effectiveness. Effectiveness here relates to whether the established policy of the Watu Ata Nature Reserve achieves its expected results (impacts) or objectives. The second is equity. The criteria for equity are closely related to competing conceptions, namely, justice and fairness with respect to ethical conflicts around a sufficient basis to distribute the rhythm of the people. This relates to justice in the enforcement of violations of the nature reserve area's policies. Responsiveness relates to how far the established policy of the nature reserve area meets the needs, preferences or values of community groups located around the nature reserve area. Appropriateness refers to the value or price of the program's objectives and the strength of assumptions that underline the goals.

\section{Methods}

This research used the descriptive qualitative research method. Bungin (2009, p. 68-69), explains that qualitative descriptive research aims to describe and summarize the various conditions, situations or phenomena of social reality existing in the community that is the object of research, and to attempt to draw the reality to the surface as a feature, characteristic, nature, model, sign or description of a particular condition, situation or phenomenon. In addition, according to Soejono and Abdurrahman (2005, p. 19), the "descriptive research method is a method which is widely used and developed in the study of social sciences because most of social research is descriptive." The purpose of the descriptive method is to describe or illustrate the existing phenomena.

The data collection techniques employed were a field study using interview, observation and documentation techniques. This field study was conducted in two villages - Heawea Village and Inelika Village - located in the Watu Ata Nature Reserve. These two villages were selected because they have the largest arable community land in the Watu Ata Nature Reserve. This can be seen in table 5 at the following discussion points. Interviews were conducted with 16 informants, divided 
as follows: representatives of the people (12 informants) and representatives of the government (4 informants). Informants were selected using the purposive sampling method, which selects informants considered to have in-depth information about the object of research and who can be trusted as complete data sources.

\section{Discussion}

\section{Effectiveness}

Effectiveness describes whether an alternative achieves the action's expected outcomes or objectives. Closely related to technical rationality, it is always measured using its product or service unit or monetary value (Dunn, 2003, p. 429). Effectiveness indicates whether the expected results from the policy setting of the Watu Ata Nature Reserve have been achieved. A policy or regulation is made with the aim of overcoming problems that occur in the community; it is similar to the policy setting of the Watu Ata Nature Reserve, which aims to protect and preserve nature (animals and plants) by allowing the growth and development process to occur naturally, without human intervention. Effectiveness indicates the results or objectives by declaring whether the setting policy of the Watu Ata Nature Reserve has been achieved. The effectiveness indicator considers:

\section{a) Policy Purpose}

When one talks about a policy's effectiveness, the primary aspect is the achievement of the policy objectives themselves. The objectives of the public sector policy are collective, which is considered a reflection of public preference or, more broadly, "public interest" (Dunn, 2003, p. 441). The purpose of policy means the goal of the policy determination of the Watu Ata Nature Reserve. The purpose of policy can serve as a benchmark of the policy success. It is common knowledge that the state sees the wealth of natural resources
(SDA) as unique, distinctive and intact, so it must be protected and preserved. Some see it as an economic asset, so the community is a threat. Meanwhile, the public sees the wealth of natural resources as their living space (life space) historically, socially, economically, ecologically and culturally (Cahyono, 2013, p. 212). This is certainly an issue that should be seriously explored in the process of setting SDA conservation goals.

Based on the definition of "nature reserve" contained in RI Government Regulation No. 28 of 2011 Article 1, it can be observed that the purpose of the policy determination of the Watu Ata Nature Reserve is to protect plant species and/or plant diversity along with natural phenomena and their ecosystem so that development and growth occur naturally. Thus, it can be said that the existence of the Watu Ata Nature Reserve has shown results that lead to the determination goal visible in the form of the presence of protected animals and plants.

Several species of mammals are protected in the Watu Ata Nature Reserve. Their numbers and proportions of abundance are as follows: 43 monkeys with an abundance proportion of $0.303 ; 36$ civets with an abundance proportion of $0.254 ; 54$ mice with an abundance proportion of $0.380 ; 2$ tree mice with an abundance proportion of 0.014 and 7 wild boars with an abundance proportion of 0.049 . In addition to mammals, there are several kinds of birds, such as 145 Philemon moluccensis (known by the local people as koka kiu), 58 Caridonax fulgidus (fega), 55 Trichoglusus eutelles (siki seka), 50 Loricus flosculus (piri) and 28 Ducula cineraceae (bawa) (The Natural Resource of Conservation Center of NTT in the area II, 2012).

The data regarding the types of mammals, birds and woody plants in the Watu Ata Nature Reserve reveal the potential of the flora and fauna in the nature reserve area which are not too flashy. From the numbers and the Shannon index of flora and fauna, one can see they are relatively small. 
Table 1.

Types of woody plants in the Watu Ata Nature Reserve

\begin{tabular}{clcc}
\hline No. & \multicolumn{1}{c}{ Species Name } & Family & Shannon Index \\
\hline 1. & Ehretia Acuminate R.Br & Boraginaceae & 0.193 \\
2. & Palaqium Obstusifolium Burk. & Sapotaceae & 0.189 \\
3. & Elattotachys Verrucosa (BL) Radlk. & Sapindaceae & 0.162 \\
4. & Tricalysa Javanica (Miq.) Kds & Rubiaceae & 0.160 \\
5. & Alstonia Spectabilis R.Br & Aponacynaceae & 0.145 \\
\hline
\end{tabular}

Source: Natural Resource Conservation Center NTT Region II, 2012

Table 2.

Types of cultivated plants in the Watu Ata Nature Reserve

\begin{tabular}{clcc}
\hline No. & \multicolumn{1}{c}{ Species Name/Local Name } & Family & Shannon Index \\
\hline 1. & Coffea Robusta/Kopi Robusta & Rubiaceae & 0.344 \\
2. & Gliricidia Sepium/ Gamal & Fabaceae & 0.280 \\
3. & Penisetum Purpureum/Rumput Gaja & Poaceae & 0.277 \\
4. & Callyandra Callothyrsus/Kaliandra & Fabaceae & 0.277 \\
5. & Vanilla Planifolia/ Vanili & Orchidaceae & 0.128 \\
\hline
\end{tabular}

Source: Natural Resource Conservation Center NTT Region II, 2012

However, another important aspect is the goal of establishing a natural reserve area to protect wild plants and wildlife whose natural survival is disturbed by the value of the natural area which is no longer fulfilled. This was proven by the existence of cultivation plants in the reserve area.

The Watu Ata Nature Reserve poses a big question. The existence of cultivated plants has become a stumbling block for the area's sustainability as a nature reserve. A review of the historical facts regarding the establishment of the Watu Ata forest area as a nature reserve reveals that utilization and management actions are part of the reserve. Another fact that reinforces the notion that the Watu Ata Nature Reserve is no longer natural is the existence of ancestral cultural sites, proving that long before the establishment of the area as a conservation forest with a function as a nature reserve, the community has managed it and made it a settlement. This can be seen in the following table of cultural sites.

The existence of these cultural heritage sites is ironic because they should be considered cultural heritage areas, not part of a nature preserve. The existence of cultural heritage sites in the Watu Ata Nature Reserve is evidence that local people have handled and managed most nature preserves. Thus, it contradicts one of the regulations related to the nature preserve area - the aspect of nature.

Another finding relates to the natural aspect of the Watu Ata Nature Reserve. According to the interviews with representatives of the community and the government, before the creation of the Watu Ata Nature Reserve, people managed it hereditarily. This fact was disclosed by several community representatives, such as Y.M.:

"We as farmers had managed the fields first and ... the ... lands of [the] Ringa and Menge tribes [are] in them. The tribal lands had been maanged for dozens of years and even hundreds of years because the tribes [had] been living in the villages before."

This statement was affirmed by one of the government representatives, the head of the village of Inelka (V.J.), who said that the 
Table 3.

Cultural sites of ancestral relics around the community in the Watu Ata Nature Reserve Area

\begin{tabular}{|c|c|c|c|}
\hline No. & $\begin{array}{l}\text { Types/Relics } \\
\text { Evidence }\end{array}$ & Location & Meaning \\
\hline 1. & Ture Nua & $\begin{array}{l}\text { Nua Ngadha, Bojawa, Waru } \\
\text { Soba, Likowali, Tolo Go, Nua } \\
\text { Bawa, Bo Ngedu and Watu Se } \\
\text { Wua }\end{array}$ & $\begin{array}{l}\text { - Stones arranged in villages that serve as supporting walls so } \\
\text { the village can avoid the scouring of rain water. } \\
\text { - Describe the etiquette that must be firmly adhered to with } \\
\text { respect to the value of cooperation. }\end{array}$ \\
\hline 2. & Ture Sao & The old villages in the area & $\begin{array}{l}\text { - A pile of rocks that strengthen the foundation of the house } \\
\text { to avoid scouring rain water. } \\
\text { - This arrangement of stones symbolizes the power that } \\
\text { homeowners possess to fight evil spirits or enemies, and also } \\
\text { symbolizes the pride of the home's owner. }\end{array}$ \\
\hline 3. & Watu Ulu & The old villages in the area & Stones grown in the village to commemorate dead ancestors. \\
\hline 4. & Watu Lengi & $\begin{array}{l}\text { The old villages in the area, } \\
\text { especially the villages of } \\
\text { Kampung Waru Soba, Susu } \\
\text { and Liko Wali }\end{array}$ & $\begin{array}{l}\text { - Stones are considered a source of coolness and peace for the } \\
\text { village. Offerings are often laid upon them, with the goal of } \\
\text { avoiding crime. } \\
\text { - In this place, the village elders decide cases, leading to fair } \\
\text { and wise decisions. }\end{array}$ \\
\hline 5. & Loka Lanu & $\begin{array}{l}\text { Mae Weko, Mara Mipi, Leko } \\
\text { Gejo, Saga Laka and Bei Radho }\end{array}$ & $\begin{array}{l}\text { - Places to conduct ancestral feeding ceremonies before the } \\
\text { Reba traditional ceremony. } \\
\text { - Places of deliberation to decide on important issues. }\end{array}$ \\
\hline 6. & $\begin{array}{l}\text { Watu Mara } \\
\text { Bawa }\end{array}$ & Wolo Bawa & $\begin{array}{l}\text { - Stone known in the folklore of Mawa Bawa. } \\
\text { - Offerings are laid here to beg for rain. }\end{array}$ \\
\hline 7. & $\begin{array}{l}\text { Watu Lego } \\
\text { Ngana }\end{array}$ & Wolo Bawa & $\begin{array}{l}\text { - Stones resembling a pig pen. } \\
\text { - Location of a ceremony to invoke crop protection from the } \\
\text { disturbance of forest pigs. }\end{array}$ \\
\hline 8. & Watu Poso & Tolo Go & A place to feed ancestors. \\
\hline 9. & $\begin{array}{l}\text { Watu Pali } \\
\text { Wai }\end{array}$ & In the middle of an old village & $\begin{array}{l}\text { - A defense symbol for the villagers. } \\
\text { - A place to take refuge from enemy attack. }\end{array}$ \\
\hline 10. & $\begin{array}{l}\text { Watu Wai } \\
\text { Adha }\end{array}$ & Wai Adha & $\begin{array}{l}\text { A place used to perform a ceremony to repel animals that } \\
\text { damage plants. }\end{array}$ \\
\hline 11. & Watu Sae & Wae Gawe & $\begin{array}{l}\text { A place to feed the ancestors and ask for their blessing before } \\
\text { planting in the garden. }\end{array}$ \\
\hline
\end{tabular}

Source: Survei Lapmas Kabupaten Ngada (2009)

fields constitute land owned by an ancestor of the local people. This is proven by the existence of Watu Lanu (piles of stone indicating that the place had been liveable before), which reveals that the land was managed dozens or even hundreds of years before its establishment as a nature reserve.

The findings related to the natural status of the Watu Ata Nature Reserve have shown that the government made a mistake in establishing the party responsible for the policy of the determination. Concrete action must be taken to establish the purpose of the policy and ensure that the people enjoy its benefits.

\section{b) Policy Target}

Every policy must have a target something with which the policy is concerned. The target is an object of the new rule or prohibition which specifically results in the loss of resources and freedom (Dunn, 2003, p. 457). So as the rule of determining the Watu Ata Nature Reserve has a target of policy. As a whole, the policy target of determining Watu Ata Nature Reserve is people in which the people are the people often villages living around the Watu Ata Nature Reserve.

The understanding about target group from the regulation that is stated by Dunn, it is answered in social problems that are 
experiencing by the societies of ten villages in around Watu Ata Natural reserve. The interview results found a lack of such policy determination. The societies state that the target communities should know about the regulations, but in fact, the communities did not receive adequate information. This is caused by a lack of socialization about the policy. Therefore, the communities claim that this policy is unilateral. Y.N said, as follows:

"It can be seen [that] the mistake [stems] from the determination process of the nature reserve area. At first, the societies [were] surprised because they [did] not know the proccess and the purpose; immediately their area became the nature reserve area. It [is] not the mistake of the societies because the areas exist[ed] before the wrong determination. There is [a] boundary but the boundary [is] through the societies' settlement area."

Dunn's statement relates to the policy of the target group. It is an object from the policy and the new probihition that especially causes the missing of resources and freedom. The chief of BKSDA Bajawa Resort, P.S., said:

"It must be claimed that the [existence] of [the] nature reserve [has] cause[d] the missing work area of societies. It has been working from one generation to [the] next generations. However, it is a heritage, so we do not need to look for the suspects of the policy determination. The important things are [that] the societies and government must work together and support each other to restore the societies' rights."

The chief of NRCC Resort Bajawa, A.T., said: "...the societies are missing the working area. Gardens are a heritage from the ancestors that [have been] taken by [the] goverment through the determination of this nature reserve area. After the determination, the goverment [also prohibited cultivating] that area."

Some statements from the above informant show that the target community in the determination of Watu Ata forest as a conservation area with the function of a nature reserve has experienced of the right ignoring. In the process of the life fullment, this problem is different with the basic value from the public determination that is directed the societies to the welfare.

\section{Equity}

Equity is whether a policy's costs and benefits are distributed evenly to the policy's target group. This concept relates to the distributed benefits it generates - in other words, whether the community perceives that it benefits from the Watu Ata Nature Reserve. Equity criteria include the concepts of competition, fairness and ethical issues surrounding the existence of an adequate basis upon which to distribute community risoris (Dunn, 2003, p. 435). With respect to the evaluation of the impact of the establishment of the Watu Ata Nature Reserve, the alignment herein relates to justice in enforcing the rules. It also relates to the non-neglect of the public interest in meeting the daily needs of the hudup, assuming that, based on Landsat TM satellite image data (November 2004) with RGB 743 band bands obtained in the Watu Ata Nature Reserve is $1657.88 \mathrm{Ha}$ (33.84\% of the area) with satellite image analysis as shown in the following table. 
Table 4.

Cultivated land area in

Watu Ata Nature Reserve based on satellite Landsat image result

\begin{tabular}{cccc}
\hline \multirow{2}{*}{ No. } & Land Cover Type/ & \multicolumn{2}{c}{ Large } \\
\cline { 3 - 4 } & \multicolumn{1}{c}{ Land Use } & Ha & \% \\
\hline 1. & Forest & 819.89 & 16.74 \\
2. & New Forest & $2,243.21$ & 45.79 \\
3. & Arable Land & $1,657.88$ & 33,84 \\
4. & Paddock & 173.74 & 3.55 \\
5. & Water & 0.87 & 0.02 \\
6. & Could & 3.21 & 0.07 \\
\hline & Amount & $\mathbf{4 , 8 9 8 . 8 0}$ & $\mathbf{1 0 0 . 0 0}$ \\
\hline
\end{tabular}

Source: Landsat TM, 2004

This fact shows that forests and forest resources in the archipelago cannot be separated from the existence of various communities that have strong social, cultural, spiritual, ecological, economic and political ties with the forest lands, territories and ecosystems (Siscawati, 2014, p. 3). In regulating the protected area, the government should not ignore the extent of the community land located within the Watu Ata Nature Reserve. This is because most of the population living around the reserve area earns its living from agriculture. Therefore, their lives and their family members' futures depend on the cultivated land they have grown within the reserve area.

The existence of community land in the Watu Ata Nature Reserve demonstrates the government's neglect of the people residing in the reserve. This is one way in which the policy lacks equity. In the interviews, members of the public expressed their disappointment with this governmental neglect. A.T. said:

\footnotetext{
"The existence of this nature reserve has caused people to lose the garden[s] and ancestor relics such as old villages. In addition, the existence of [the] nature reserve ha[s] also caused people to experience shortages of land to plant. And for us, [the] Heawea community, [the] nature reserve [inhibits] entry transportation to our village."
}

It should be noted that Heawea is one of the villages that has no access to transportation. The community's mobility relies on physical strength, with members walking tens of kilometres to reach the centre of trade or market and the district government centre.

A.K. made a statement reinforcing A.T.'s point of view:

"With the existence of this nature reserve has caused the community to lose the garden and ancestral heritage such as old village (NuaOlo), in addition to the existence of nature reserves have also caused people to experience shortage of land to plant. And for us, Heawea community nature reserve is also one causes and obstacles to transport entry into our village."

F. D, village head of Heawea, asserted:

"The government prohibits the community [from] manag[ing] the claimed land that has been managed by the community for generations and the land of inheritance. We know that almost $99 \%$ of the people in Heawea village are farmers and the gardens are supporting their economy."

The facts stated by the informants differ from the research conducted by the Nasuri (2014, p. 783-801). The Nigerian government, in implementing forest cultivation efforts, is still concerned with the rights and needs of societies. This model can certainly be applied in forest management efforts undertaken by the government so that both parties - the government and the community-can experience the expected impact of policy determination associated with forest management.

This fact should be an important consideration among the parties concerned. Thus, the burning of the farmer's cottage on August 2, 2001, and the burning of 13 farmers' 
Picture 1.

Map of arable land located in the Watu Ata Nature Reserve

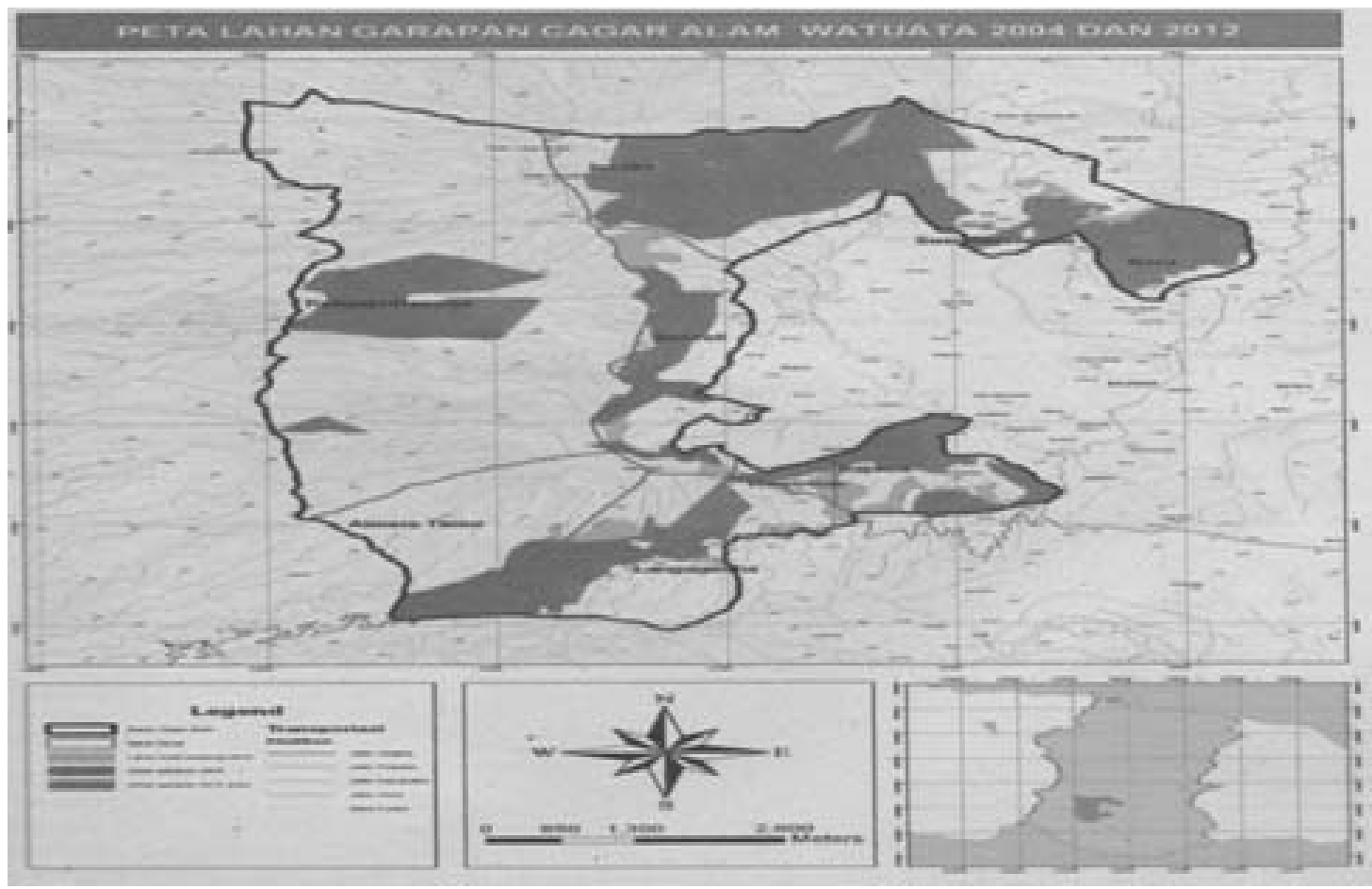

Source: Natural Resource Conservation Center NTT Region II 2012

lodges in the Lodo/Ghole area on November 14, 2002 was unnecessary. The policies should consider all the impacts resulting from the policy determination, such that the implementation neither harms nor benefits any party. This aligns with research conducted by Guan (2015, p. 467-483), revealing that the Chinese government's efforts to combat illegal logging had a negative impact on the ability to meet the demand for forest products from Chinese forest product companies, A more in-depth review is necessary to determine how forests can remain protected through the prohibition of illegal logging while, at the same time, the demand for forest products is met. The Chinese government is seeking alternatives to meet the needs for forest products not sourced from illegal logging. Therefore, efforts to protect the Watu Ata forest area through the policy of the Watu Ata Nature Reserve must be reviewed so that the policy accommodates the needs of all those who depend on the forest.

\section{Responsiveness}

Responsiveness regards the extent to which a policy can satisfy the needs, preferences or values of particular community groups. The criteria for responsiveness are important because the analysis can satisfy all other criteria. Effectiveness, efficiency, adequacy and equity fail if the actual needs of the group who should benefit from a policy have not been addressed (Dunn, 2003, p. 437).

It can be said that the policy of determining the Watu Ata Nature Reserve does not fulfill the needs and values of the people who live in the nature reserve area, who are the policy's target group. The determination policy of the Watu Ata Nature Reserve limits the community's efforts to fulfil their needs and to implement the cultural values that exist and develop in their environment. People living in the vicinity of the nature reserve require the restoration of arable land management rights. As D.N. said: 
"We only expect [that] all our rights to the garden and the ancestors' relics in the form of nuaolo (old village) [be] returned."

K.M. made a similar statement:

"Release the land and community gardens and cultural assets and change the status of the area so people can still manage the existing gardens."

In line with the above statements, Y.D. said:

"Restore the rights of our farmers
around the nature reserve by refining
the boundary, and if we want to
preserve the forest, the government
can work with the community."

Community members need the land to support their families. In addition, the area's cultural sites are sacred places where community members build close relationships with their ancestors. Social problems experienced by communities around the nature reserve align with Djadmiko (2007, p. 142), who found that authority management in the Mandor Nature Reserve implemented by the central goverment (forestry department) - in this case, the Natural Resource Conservation Center (NRCC) of West Kalimantan - is concerned with protection and does not include conservation principals such as preservation and utilization. Access is closed to the public, so the management (which has been carried out as a conservation effort) has not provided economic benefits to the surrounding community. Communities are prohibited from carrying out activities deemed damaging to the existence of the Mandor Nature Reserve. Thus, with respect to the Mandor Nature Reserve, the purpose of conservation - to maintain an ecological balance and improve the community's welfare without damaging the environment - has not been achieved.
The demand for the restoration of community rights stems from the expropriation of forest area from the community, which was carried out unilaterally and which has harmed the community. N.L. discussed the government's unilateral takeover the community's rights:

“...the area determination [was] done without the involving of societies. We as the societies re not feeling do mistake because together with goverment before the determination around 1980. We did the reforestation program, and the the policy about the nature reserve area is naturally, it never touches by a human. This case absolutely is confusing us because our garden[s] belong to [the] nature reserve area and where is the natural factor? In my opinion, [this is a] mistake because it is unilateral from [the] government and [did not involve the] societies."

P.S. (chief of NRCC Ngada resort) made a similar statement:

“The societies' garden[s] belong to the nature reserve area because the goverment [made a] mistake [and] did not conduct [an] accurate survey when the boundary [was determined]."

In the conclusion of his research results, Pramono (2014, p. 229) asserted that indigenous peoples are still experiencing political challenges from government policy practices regarding customary territories that do not change even with the existing Court Decision 35. For example, the Ministry of Forestry strives to maintain as much authority as possible over state forest areas though be In areas of indigenous peoples. The most prominent policy product is the Regulation of Forestry Ministry Number P.62/MenhutII/2013, about the establishment of the forest area, created in response to the decision of MK 35 about the customary forest. Instead of facilitating 
Table 5.

Total area of village administration included in the Watu Ata Nature Reserve

\begin{tabular}{ccccc}
\hline No. & $\begin{array}{c}\text { Village Name/Urban } \\
\text { Village }\end{array}$ & $\begin{array}{c}\text { Village Area } \\
\left(\mathbf{k m}^{\mathbf{2}} \mathbf{m}\right.\end{array}$ & $\begin{array}{c}\text { Total } \\
\text { Population }\end{array}$ & Villages Within the Area (\%) \\
\hline 1. & Wawowae & 9.75 & 2,067 & 2.97 \\
2. & Beiwali & 13.42 & 1,566 & 11.33 \\
3. & Susu & 20.00 & 4,084 & 2.5 \\
4. & Naru & 8.74 & 1,945 & 23.34 \\
5. & Langagedha & 6.67 & 822 & 22.52 \\
6. & Bajawa & 5.46 & 2,746 & 19.23 \\
7. & Keligejo & 16.00 & 1,097 & 0.88 \\
8. & Haewea & 9.62 & 483 & 26.61 \\
9. & Inelika & 11.15 & 1,909 & 29.09 \\
10. & Bomari & 4.43 & 1,373 & 0 \\
\hline
\end{tabular}

Source: Ngada in the numbers in 2012

the removal of the customary forest from state forest areas, the regulation makes it difficult for indigenous peoples to gain constitutional rights over their territory. Communities surrounding the Watu Ata Nature Reserve experience all these stages.

Based on research conducted by Cahyono (2012: 7-41), what is felt by the community around the Watu Ata Nature Reserve is also felt by the people around Ujung Kulon National Park. This research revealed that the policy that created Ujung Kulon National Park to protect its flora and fauna, through Decree of the Minister of Forestry No. 284/Kpts-II/1992, with a total area of $120,551 \mathrm{Ha}$, resulted in a loss of access for people living in the area and, consequently, in the loss of their livelihood. Inhabitants were accused of encroaching on the forest area. However, historical facts reveal that the community around Ujung Kulon National Park had long utilized the forest area to fulfill their daily needs because the population's background is in agriculture.

\section{Appropriateness}

The criterion of accuracy relates closely to rationality and substantiveness because the question of policy precision is not concerned with individual criterion but with two or more criteria together. Accuracy refers to the program objectives' value or price and to the strong assumptions underlying those goals (Dunn, 2003, p. 438).

The determination of the Watu Ata forest area as a nature reserve reveals a contradiction between the rule of law as the foundation of the decree's implementation and the facts found in the field. This indicates that, in the process of determination, the government did not conduct an in-depth study of the administrative areas (as seen in the following table) residing in the nature reserve area.

In the explanation of the preceding points, the author has expressed another fact revealing the existence of contradictions. The overall facts disclosed lead to the conclusion that the determination of the Watu Ata forest area as a nature reserve was an improper decision and has negatively affected the communities living around the reserve area. It is also contributing to the struggle the communities around the nature reserve are facing with respect to the restoration of their rights to arable land and cultural sites.

Several organizations have been created to fight the harmful policy. One is the Societies Community of Watu Ata Environment Caring (FORMATA), which later became the Societies Association of Watu Ata (PERMATA). Such organizations are carrying out activities that give them hope. These activities include The 
Big Discussion in 2009 and peace activism in 2011. The communities are fighting to get back their rights. In 2014, the local government helped communities that had complained to the Forestry Ministry. Unfortunately, however, all the struggles have not yet produced results. The communities are still experiencing social exclusion in the utilization of their land.

This problem aligns with the research conducted by Verbist (2004, p. 20-28), which found negative community impacts related to the enactment of the Barisan Selatan National Park determination, Policy Letter based on Ministerial Decree No. 67/1991; the area covers the village and agroforestry resin (Repong Damar). The results of the 1998 calculations show that the Krui coast contains 29,000 ha of Repong Damar and other land uses that, during the administration of the Netherlands, were not classified as forests, changing their status to national parks. In fact, up to now, indigenous communities have managed most of the Repong Damar for over 100 years. The determination of this policy created conflict between the local community and the government.

Similar results were expressed in the findings of research conducted by Guan (2015, p. 467-483), which reveal that the Chinese government's efforts to combat illegal logging had a negative impact on the ability to meet the demand for forest products from forest product companies in China. A need exists for a deeper review of how forests can remain protected while, simultaneously, forest product needs can remain fulfilled.

\section{Conclusion}

The Watu Ata Nature Reserve is proof that the people in this area are not apathetic to the developments and changes taking place in their lives as a result of policies issued and determined. Their struggles are driven by the losses they experienced due to the establishment of the nature reserve area.
Based on the four criteria the authors used to evaluate the Watu Ata Nature Reserve policy, one can see that the determination policy has had a negative impact on the people living around the nature reserve. Therefore, it is necessary to reformulate the Watu Ata Nature Reserve policy in a way that enables the community to continue managing the land that is the foundation for their future while still maintaining and preserving nature. The realization of this will require constructive cooperation between all parties involved, including the community, traditional leaders and the government-both the local government and the Ministry of Forestry. The government can seek the wisdom of local people with respect to forest management efforts and adopt this wisdom in its policy. This recommendation for cooperation is similar to that achieved in the secondary forest utilization described by Hwang (2016, p. 72-92). Cooperation between various parties constitutes a participatory effort undertaken to shift the topdown determination system.

\section{References}

S, M. A., M., \& Prasetya, W. Y. (2014). Evaluasi dampak kebijakan pembangunan Pelabuhan Perikanan Pantai (PPP) Tamperan terhadap perubahan sosial ekonomi masyarakat pesisir sekitar (Studi Kasus pada PPP Tamperan Kab. Pacitan). Jurnal Administrasi Publik, 2(11), 1010-1015.

Bungin, B. (2009). Penelitian kualitatif: komunikasi, ekonomi, kebijakan publik, dan ilmu sosial lainnya. Jakarta: Kencana Prenada Media.

Cahyono, E. (2013). Eksklusi atas nama konservasi (studi kasus masyarakat sekitar/dalam kawasan Taman Nasional Ujungkulon Banten). Jurnal Sosiologi Reflektif, 8(1), 209-245. Retrieved from http://ejournal.uin-suka.ac.id/isoshum/ sosiologireflektif/article/view/519.

Dunn, W. N. (2003). Pengantar analisis kebijakan publik. Yogyakarta: Gadjah Mada University Press. 
Djadmiko. (2007). Evaluasi pengelolaan kawasan cagar alam mandor di kabupaten Landak Propinsi Kalimantan Barat (Master's thesis, Semarang, 2007). Semarang: Universitas Diponegoro.

Guan, Z., \& Gong, P.(2015). The impacts of international efforts to reduce illegal logging on China's forest products trade flow. China Agricultural Economic Review, 7(3), 467-483. doi: 10.1108/caer-12-20140134

Government Regulation of the Republic of Indonesia No. 28 of 2011 on Management of Nature Reserve Area and Nature Conservation Area

Hwang, Y. H., Feng, Y., \& Tan, P. Y. (2016). Managing deforestation in a tropical compact city (Part B): Urban ecological approaches to landscape design. Smart and Sustainable Built Environment, 5(1), 73-92. doi: 10.1108/sasbe-08-2015-0023

Koli, Y. (2010). Mengubah Cagar Alam Watu Ata (Sebuah Pengalaman Advokasi Kebijakan Publik): Sloka institute, Lapmas Ngada, dan VECO Indonesia

Koli, Y. (2009, November 9). Bongkar Ulang Cagar Alam Watu Ata. Tribunnews. Retrieved March 3, 2016 from http:// kupang.tribunnews.com/2009/11/09/ bongkar-ulang-cagar--alam-watu-ata.

Kusumanegara, S. (2009). Model dan aktor dalam proses kebijakan publik. Yogyakarta: Gava Media.

Mulyadi, D. (2015). Studi kebijakan publik dan pelanan publik. Bandung: Alfabeta.
Medugu, I. N., Majid, M. R., Johar, F., \&Taiwo, I. S. (2014). Assessing the impact of Forestry II program on agricultural productivity in the Arid Zone of Nigeria: A case of Kano and Jigawa State. Management of Environmental Quality: An International Journal, 25(6), 783801. doi: 10.1108/meq-05-2013-0038

Parsons, W. (2008). Public policy: pengantar teori dan praktikanalisis kebijakan. Jakarta: Kencana.

Pramono, A. H. (2014). Perlawanan atau Pendisiplinan? Sebuah Refleksi Kritisatas Pemetaan Wilayah Adat. Wacana Jurnal Transformasi Sosial. 33, 207-242.

Subarsono, AG. (2013). Analisa kebijakan publik, konsep, teori dan aplikasi. Yogyakarta: Pustaka Pelajar.

Kementerian Kehutanan. (2014). Statistik kementerian kehutanan. Jakarta: Kementerian Kehutanan.

Tim Inkuiri Nasional Komnas HAM. (2016). Inkuiri Nasional Komisi Nasional Hak Asasi Manusia: Hak Masyarakat Hukum Adat Atas Wilayah di Kawasan Hutan. Jakarta: Komisi Nasional Hak Asasi Manusia Republik Indonesia

Babak Baru Perjuangan Rakyat Watu Ata. (2011, May 10). Retrieved March 3, 2016, from http://www.berdikarionline.com/babak-baruperjuangan-rakyat-watu-ata/

Verbist, B.\&Pasya, G. (2004). Perspektif sejarah status kawasan hutan, konflik dan negosiasi di Sumberjaya, Lampung Barat-Propinsi Lampung. Jurnal Agrivita, 26(1), 20-29.

Wibawa, S. (1994). Evaluasi kebijakan publik. Jakarta: Raja Grafindo Perkasa. 